\title{
PORTFOLIO-BASED BENCHMARKS AND THE LONG-TERM PERFORMANCE OF SEOS FOR AN EMERGING MARKET
}

The paper focuses on the long-term price performance after seasoned equity offerings (SEOs). In particular, the research contributes to the debate on the importance of the benchmark design in an emerging market. The choice of Indian SEOs as a sample allowed for constructing six benchmarks and comparing the results with the main market index. The study confirmed three-year underperformance for all of the benchmarks. However, the level of abnormal long-term returns appeared to be very sensitive to the benchmark. Interesting conclusions also emerged from differentiating the sample according to the level of the shortterm underpricing, company and issue size, market sentiment, and mean volatility of prior returns. While the conventional view was that SEOs underperform in the long run, the research showed that average abnormal returns, differentiated according to firm and issue characteristics, were very sensitive to the reference portfolio.

Keywords: seasoned equity offerings, abnormal returns, benchmark, market reaction, market anomalies

DOI: $10.15611 /$ aoe.2018.2.18

\section{INTRODUCTION}

Is investing for longer periods in firms offering equity after going public (seasoned equity offerings, SEOs) a certain way of losing money? A vast number of studies conclude that it was almost impossible for an SEO company to beat the stock market or a group of similar firms.

Global issuing activity in seasoned public offerings has fluctuated over past decades. The price behavior after issuing has attracted a lot of attention from researchers from the empirical as well as the theoretical point of view. The seasoned equity issue puzzle has been well documented for the US market, but international evidence is also quite common. One of the most controversial and surprising topics in the literature on the market reaction to equity financing is the negative long-term abnormal performance in the years following seasoned equity offerings. Most of the previous studies confirmed that SEOs generally tend to underperform in the market. Such

\footnotetext{
* Corporate Finance Department, Poznań University of Economics.
} 
a reaction was observed by Loughran and Ritter (1995), Spiess and AffleckGraves (1995), Jegadeesh (2000) and Eberhart and Siddique (2002). These researches inclined to search for an explanation for such a (negative) performance and for such long-lasting reaction. On the other hand, Eckbo et al. (2000), Brav et al. (2000) and Li and Zhao (2006) observed that there was no evidence for the underperformance after SEOs, especially when new matching techniques were applied. Such results raise doubts as to whether the long-term underperformance does exist or is just a consequence of the inability of the matching techniques to control properly all risk factors.

The general aim of the study was to discuss the benchmark choice consequences for the long-term performance of equity prices after SEOs issued in an emerging market. Because of that, the choice of the stock market could not be accidental as a huge universe of listed companies was crucial for benchmark construction. The Indian capital market is one of the biggest emerging equity markets. The Bombay Stock Exchange and the National Stock Exchange of India were selected as they were the 10th and 11 th largest in the world by market capitalization.

The study focused on three detailed issues. First, what was the performance of seasoned equity offerings in the Indian market, as an example of an emerging market. Second, if this anomaly did exist, whether it was distinct for groups differentiated by firm and offering characteristics. And third, if these groups showed different patterns, whether the benchmark choice did matter or not.

The study was financed by the National Science Center, Poland as a research project (2015/19/D/HS4/01950). The paper proceeds as follows. The next section briefly presents the existing literature and the results of prior studies on SEOs, focusing especially on the benchmark portfolio selection. Section 3 contains a discussion of the benchmarks used to evaluate the long-term performance and describes the dataset. The empirical results are presented in Section 4. The final section gives a summary of findings.

\section{RELATED RESEARCH}

The Indian equity market is one of the oldest in the world. The number of firms listed in the Indian market is large. However, Indian market capitalization has been relatively small in comparison to other world markets for many years, growing in importance in recent years. Due to this, the number of empirical studies focused on Indian public equity offerings is increasing. 
The Indian market has been investigated mainly with the focus on initial public offerings (IPOs). Several studies documented short-term IPO performance, e.g. Madhusoodan, Thiripalraju (1997), Nandha, Sawyer (2002), Singh, Mittal (2003), Pandey (2004), Ghosh (2005), Sehgal, Singh (2007), Singh, Mittal (2005), Mayur, Kumar (2006), Sehgal, Singh (2008), Garg, Arora and Singla (2008), Deb (2009), Bhatia and Singh (2012), Goyal, Singh (2014).

So far Indian seasoned equity offerings have not been examined as thoroughly as IPOs. Some studies focused on specific issues of SEOs, e.g. the book-building process for the years 1999-2007 (Kumar 2007), the operating performance after issuance for 1991-2000 (Lukose, Rao 2003), the choice between qualified institutional placements and rights issues for 20062010 (Tuli, Shukla 2014) or short-term $(-30 ;+30$ day event window) price reaction to an announcement of a rights issue for 1997-2005 (Marisetty, Marsden, Veeraraghavan 2008).

The existing studies on the long-term SEO performance include Deb and Kamisetty (2015) with the period covering January 2000 to March 2014. SEOs firm performance was compared to firms from the same industry which were similar in other parameters with propensity score measure. Deb (2017) examines SEOs from 2003-2015 with propensity score matching.

Though the evidence is less definitive than for short-term price behavior, a large body of academic literature has documented the substantial long-term underperformance as a result of seasoned equity offerings for other markets but the issue is well-documented for the US. A vast number of papers for the emerging markets presents empirical results with an existing index as a benchmark, omitting important risk factors. As such, these results have to be interpreted with caution as the negative abnormal returns could be a result of the inability to precisely measure the abnormal performance. One of the critical issues is the choice of a benchmark.

Methods of abnormal return calculation after company events (not only for SEOs) were the subject of heated discussion in previous studies such as Barber and Lyon (1997), Kothari and Warner (1997), Fama (1998), Loughran and Ritter (2000). The most common way for abnormal returns calculation in long-term event studies was the comparison to the existing market indexes. Such a benchmark was used for example by Brav et al. (2000) and Jegadeesh (2000). Early studies concluded that securities tended to underperform in the market after seasoned equity offerings. Although matching by a market index is a relatively easy and a convenient benchmark to be applied, it also has deficiencies. This is mostly due to the problems 
with controlling for risk correctly. Ahern (2009) pointed out that the comparison only to a market index could be misleading as there would still remain doubts if the average security performance was a long-term result of the offering event, or whether it was just the consequence of firm characteristics unrelated to the fact of issuing. As a consequence, there appeared attempts to measure the performance after events in comparison to other firms with similar risk. The benchmark can be a control firm as well as a reference portfolio (see Ang and Zhang (2002) for discussion). Moreover, it is possible to match according only to a company feature (firm size can be an example). However, better matching is expected to be achieved when the reference return is calculated according to many dimensions simultaneously (e.g. size and performance).

Size-matching was applied for the US market by Spiess and AffleckGraves (1995) and Loughran and Ritter (1995). Spiess and Affleck-Graves used two-dimensional matching to select a control firm (according to the industry group and size or size and book-to-market ratio). Two-dimensional matching was also proposed by Lyon et al. (1999) and Eckbo et al. (2000), or Li and Zhao (2006). Brav et al. (2000) and Li and Zhao (2006), matched with the three-dimensional procedure according to the size, book-to-market ratio and prior returns. The requirement of a relatively huge universe of companies makes it sometimes impossible to apply it to small or even medium exchanges.

The study proposes to discuss the abnormal long-term SEO performance for a range of benchmarks which is quite new for emerging markets as such, and the method used in the paper has not been applied to the Indian equity market.

\section{DATA SOURCES, SAMPLE DESCRIPTION AND METHODOLOGY DESIGN}

The source for SEOs and the related data (adjusted stock prices, indexes, financial statement information) was the Thomson One Banker database. The initial sample consisted of all seasoned equity transactions completed worldwide. Then, only the Indian SEOs were selected, with proceeds totaling US $\$ 54,214$ million. The dataset included seasoned equity offerings completed by companies listed on the Bombay Stock Exchange (BSE) and the National Stock Exchange of India (NSE) from 2004 to 2011. The main sample used in the research consisted of 865 seasoned equity offerings. The data for seasoned equity offerings, information about stock prices, index 
values and financial statement information were not always uniform and comprehensive, so transactions and companies with missing data were excluded from the final research sample.

Matching to similar firms was based on the assumption that the investment risk of securities can be explained by a set of its characteristics. The benchmark portfolio approach was applied instead of individual control firm matching. Seven different reference portfolios were used. The first groups of benchmarks comprised of market indexes. The first one was the existing market index, the BSE 500 Index (IDX) to ensure the comparison to the other studies on SEOs. Next, two additional general market indexes were built, mainly, the equally and value weighted average return on all stocks listed on the BSE and NSE and reported in the Thomson Reuters database for a particular trading day (ALL_EqW and ALL_VW, respectively).

In the next step, a reference portfolio was limited only to non-SEO firms. Each SEO company was excluded from the non-SEO benchmark sample for other events during a period of from three years before and up to three years after the offering date. The aftermarket performance was measured with the use of the equally and value-weighted average daily return on all non-SEO securities (nSEO_EqW and nSEO_VW, respectively).

Abnormal performance was also measured against similar non-offering securities. Here, two characteristic-based portfolios were built. The first was based on the firm size (Cap_EqW) and the second compared according to the size and book-to-market ratio (Cap_BM_EqW). The size was expressed with the average market value of equity (capitalization) for the year before SEO. The book-to-market ratio was measured using the book value of equity for the most recent year before SEO. Capitalization and book value were in US dollars. Size portfolios were generated by forming size deciles using all of the BSE and the NSE firms. The breakpoints for those portfolios were calculated annually for the most recent year before the offering. The portfolio formation was repeated annually. Then the benchmark return was calculated on a daily basis as the average of returns of all non-SEO firms belonging to the same size decile. Next, two-dimensional matching was applied. The size and book-to-market portfolios were created by first forming size quartiles for the BSE and the NSE firms. Then, within each size quartile, book-to-market quartile breakpoints were formed. The BSE and the NSE firms were allocated into those 16 portfolios. The portfolio formation according to size and book-to-market ratio was repeated annually. Size and book-to-market quartiles were used instead of deciles because there were too few companies after matching according to deciles. Average daily returns for 
companies in each of the 16 portfolios were then calculated and each SEO firm was referred to the appropriate portfolio.

After defining the benchmark, buy-and-hold returns were generated for the selected investment period. It was assumed that a quarter and a year equal 63 and 252 trading days, respectively. The final results were observed up to three years. Buy-and-hold returns (BHAR) were applied to create a trading situation of an investment in securities at the offering time, holding it during a specified period of time and selling it afterwards. Buy-and-hold returns were also used to account for the rebalancing bias which could arise when cumulative returns would be employed. The abnormal return for each offering was the simple difference between the buy-and-hold return on the SEO security and the corresponding benchmark. Buy-and-hold returns were achieved by compounding daily returns for each security and by compounding average daily returns for the reference portfolio. To minimize the potentially detrimental effect of extreme outliers, the literature was followed and the sample was decreased so that the buy-and-hold returns for an investment period were between the 1st and 99th percentiles, respectively.

The statistic test choice is a difficult task in long-term event studies. Parametric tests (especially the Student's $t$-test) are most commonly used even when their requirements are not fulfilled. Thus the non-parametric Wilcoxon signed rank test can be used instead. Some of the misspecification errors in the Student's $t$-test that are caused by the skewness of the population distribution can be solved by the use of Johnson's test statistics (1978). As Kothari and Warner (1997), Barber and Lyon (1997) and Lyon et al. (1999) showed, the conventional parametric test often confirmed the long-run abnormal performance when none was present. Here, the results of the parametric traditional $t$-test were presented along with the skewnessadjusted $t$-statistics to account for the skewness bias. The nonparametric signed rank Wilcoxon test was also applied to support the conclusions. The null hypothesis of no abnormal long-term returns for SEOs was tested. The statistical significance was presented according to the conventional confidence levels.

In the next step, the sample was divided into groups according to the median value for each of the six characteristics calculated for the Indian SEO sample. The sample was split into those groups with the use of: the short-term underpricing (short-term return calculated as the first trade date price to the offer price), the company size (average capitalization for the year before the offering), the issue size (total proceeds for the issue), the 
market sentiment around the issue (BSE 500 Index average return in the period of twenty days before and after the offering date), the prior security performance (average return on the SEO security in the period of 252 trading days before the offering) and information asymmetry (volatility of security returns measured as the average standard deviation of security prices of the issuer in the period of 252 trading days before the offering). The differences between the two groups (with the value below and above the median, for each of the six ratios) were tested with the use of the Mann-Whitney U-test.

Table 1

Descriptive average statistics for Indian SEOs

\begin{tabular}{l|c|c|c}
\hline & & Mean & Median \\
\hline Short-term underpricing & {$[\%]$} & 10.56 & 0.90 \\
\hline Company size & {$[$ US \$, millions] } & $18,335.4$ & 579.2 \\
\hline Issue size & {$[$ US \$, millions] } & 62.7 & 5.2 \\
\hline Market sentiment around the issue & {$[\%]$} & 0.05 & 0.09 \\
\hline Prior security performance & {$[\%]$} & 0.22 & 0.10 \\
\hline Proxy for information asymmetry before SEO & {$[\%]$} & 4.90 & 3.68 \\
\hline
\end{tabular}

Source: author's own.

The summary statistics about the whole sample are shown in Table 1. It gives a basic understanding of the magnitude of the short-term performance, the firm- and issue-characteristics around the issue date. For many firm and transaction characteristics the distribution is skewed. The table gives a general idea about the firm and market characteristics around the time of offering in the Indian market.

\section{POST-OFFERING STOCK RETURN PERFORMANCE}

The research revealed the substantial underperformance of Indian SEO firms up to three years after offering, even after adjusting for risk. The detailed results for the long-term performance of SEOs (measured with buyand-hold abnormal returns) for the set of reference portfolios are presented in Table 2. The statistical significance was checked with the parametric as well as the non-parametric tests. Figure 1 illustrates the buy-and-hold abnormal returns for reference portfolios for quarters of the three-year period for seven benchmarks. 
Table 2

Long-term performance of SEOs for different reference portfolios

\begin{tabular}{|c|c|c|c|c|c|c|c|c|c|c|c|}
\hline \multirow{2}{*}{$\mathrm{T}$} & \multirow{2}{*}{$\begin{array}{c}\text { Mean } \\
{[\%]}\end{array}$} & \multirow{2}{*}{$\begin{array}{c}\text { Median } \\
{[\%]} \\
\end{array}$} & \multirow{2}{*}{ Std [\%] } & \multirow{2}{*}{ Skewness } & & & \multicolumn{3}{|c|}{$p$-value } & & \multirow{2}{*}{$\mathrm{N}$} \\
\hline & & & & & \multicolumn{2}{|l|}{$t$-test } & \multicolumn{2}{|c|}{ Skewness-adj. $t$-test } & \multicolumn{2}{|c|}{ Wilcoxon test } & \\
\hline \multicolumn{12}{|c|}{ Panel A IDX } \\
\hline $1 \mathrm{Y}$ & -6.2 & -14.8 & 49.2 & 1.1 & 0.0030 & $* * *$ & 0.0046 & $* * *$ & 0.0000 & $* * *$ & 554 \\
\hline $2 \mathrm{Y}$ & -12.3 & -28.0 & 73.3 & 1.2 & 0.0019 & $* * *$ & 0.0039 & $* * *$ & 0.0000 & $* * *$ & 344 \\
\hline $3 \mathrm{Y}$ & -28.3 & -36.7 & 69.7 & 0.6 & 0.0000 & $* * *$ & 0.0000 & $* * *$ & 0.0000 & $* * *$ & 174 \\
\hline \multicolumn{12}{|c|}{ Panel B ALL_EqW } \\
\hline $1 \mathrm{Y}$ & -44.2 & -55.1 & 68.9 & 1.5 & 0.0000 & $* * *$ & 0.0000 & $* * *$ & 0.0000 & $* * *$ & 586 \\
\hline $2 \mathrm{Y}$ & -123.5 & -136.5 & 105.2 & 1.5 & 0.0000 & $* * *$ & 0.0000 & $* * *$ & 0.0000 & $* * *$ & 365 \\
\hline $3 \mathrm{Y}$ & -258.9 & -267.1 & 124.9 & 0.7 & 0.0000 & $* * *$ & 0.0000 & $* * *$ & 0.0000 & $* * *$ & 190 \\
\hline \multicolumn{12}{|c|}{ Panel C ALL_VW } \\
\hline $1 \mathrm{Y}$ & -24.1 & -26.2 & 57.3 & 0.3 & 0.0000 & $* * *$ & 0.0000 & $* * *$ & 0.0000 & $* * *$ & 546 \\
\hline $2 \mathrm{Y}$ & -77.9 & -70.7 & 109.8 & 0.1 & 0.0000 & $* * *$ & 0.0000 & $* * *$ & 0.0000 & $* * *$ & 340 \\
\hline $3 \mathrm{Y}$ & -239.9 & -212.6 & 185.6 & -0.5 & 0.0000 & $* * *$ & 0.0000 & $* * *$ & 0.0000 & $* * *$ & 174 \\
\hline \multicolumn{12}{|c|}{ Panel D nSEO_EqW } \\
\hline $1 \mathrm{Y}$ & -46.7 & -54.0 & 53.4 & 0.7 & 0.0000 & $* * *$ & 0.0000 & $* * *$ & 0.0000 & $* * *$ & 545 \\
\hline $2 \mathrm{Y}$ & -118.9 & -127.0 & 79.9 & 0.6 & 0.0000 & $* * *$ & 0.0000 & $* * *$ & 0.0000 & $* * *$ & 342 \\
\hline $3 \mathrm{Y}$ & -248.2 & -250.0 & 103.2 & 0.0 & 0.0000 & $* * *$ & 0.0000 & $* * *$ & 0.0000 & $* * *$ & 173 \\
\hline \multicolumn{12}{|c|}{ Panel E nSEO_VW } \\
\hline $1 \mathrm{Y}$ & -28.0 & -29.1 & 57.9 & 0.3 & 0.0000 & $* * *$ & 0.0000 & $* * *$ & 0.0000 & $* * *$ & 545 \\
\hline $2 \mathrm{Y}$ & -101.4 & -80.9 & 130.1 & -0.3 & 0.0000 & $* * *$ & 0.0000 & $* * *$ & 0.0000 & $* * *$ & 343 \\
\hline $3 \mathrm{Y}$ & -323.5 & -290.1 & 238.1 & -0.3 & 0.0000 & $* * *$ & 0.0000 & $* * *$ & 0.0000 & $* * *$ & 174 \\
\hline \multicolumn{12}{|c|}{ Panel F Cap_EqW } \\
\hline $1 \mathrm{Y}$ & -35.1 & -32.7 & 69.7 & -0.8 & 0.0000 & $* * *$ & 0.0000 & $* * *$ & 0.0000 & $* * *$ & 504 \\
\hline $2 \mathrm{Y}$ & -90.2 & -64.1 & 157.9 & $\begin{array}{ll}-1.8 \\
\end{array}$ & 0.0000 & $* * *$ & 0.0000 & $* * *$ & 0.0000 & $* * *$ & 314 \\
\hline $3 \mathrm{Y}$ & -202.9 & -106.7 & 298.1 & -2.1 & 0.0000 & $* * *$ & 0.0000 & $* * *$ & 0.0000 & $* * *$ & 155 \\
\hline \multicolumn{12}{|c|}{ Panel G Cap_BM_EqW } \\
\hline $1 \mathrm{Y}$ & -20.2 & -23.5 & 58.4 & 0.4 & 0.0000 & $* * *$ & 0.0000 & $* * *$ & 0.0000 & $* * *$ & 339 \\
\hline $2 \mathrm{Y}$ & -50.4 & -50.1 & 108.3 & -0.5 & 0.0000 & $* * *$ & 0.0000 & $* * *$ & 0.0000 & $* * *$ & 197 \\
\hline $3 \mathrm{Y}$ & -76.9 & -54.6 & 172.8 & -3.3 & 0.0001 & $* * *$ & 0.0000 & $* * *$ & 0.0000 & $* * *$ & 89 \\
\hline
\end{tabular}

Notes: Benchmarks: IDX (BSE 500 Index); ALL_EqW (equally weighted average return on all stocks); ALL_VW (value weighted average return on all stocks); nSEO_EqW (equally weighted average return on all non-SEO stocks); nSEO_VW (value weighted average return on all non-SEO stocks); Cap_EqW (equally weighted average return on all stocks in the capitalization decile); Cap_BM_EqW (equally weighted average return on all stocks in the capitalization and book-to-market quartiles). Statistical significance at the $1 \%(* * *), 5 \%(* *)$ and $10 \%(*)$ confidence levels.

Source: author's own.

The average BHARs were negative, regardless of the benchmark used. The results were statistically significant not only with the t-test but also according to the t-test adjusted for skewness and the Wilcoxon signed rank test. However, the level of negative BHARs differed substantially according to the benchmark. The market index matching resulted in the least negative abnormal returns. The most negative BHARs were observed for five benchmarks: ALL_EqW, ALL_VW, nSEO_EqW, nSEO_VW, Cap_EqW. The average buy-and-hold returns calculated with matching by size and book-to-market ratio (Cap_BM_EqW) were both in the middle. 


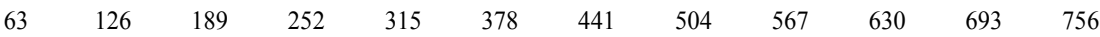

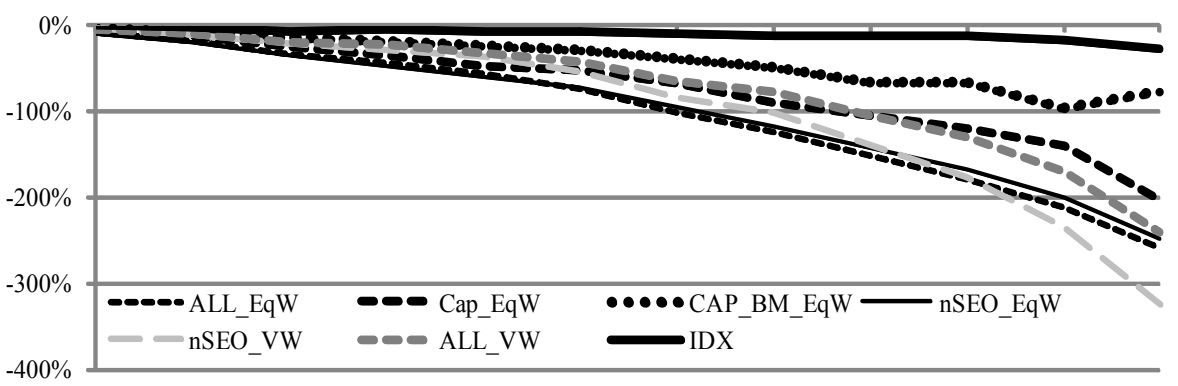

Figure 1. Buy-and-hold abnormal returns for reference portfolios

Source: author's own.

Table 3

Three-year abnormal performance by SEO characteristics

\begin{tabular}{|c|c|c|c|c|c|c|c|}
\hline \multirow{2}{*}{ Benchmark } & \multirow{2}{*}{$\begin{array}{c}\text { Mean } \\
{[\%]}\end{array}$} & \multirow{2}{*}{$\begin{array}{c}\text { Median } \\
{[\%]}\end{array}$} & \multirow{2}{*}{$\mathrm{N}$} & \multicolumn{4}{|c|}{$p$-value } \\
\hline & & & & $t$-test & Skewness adj. t-test & Wilcoxon test & Mann-Whithey test \\
\hline 1 & 2 & 3 & 4 & 5 & 6 & 7 & 8 \\
\hline
\end{tabular}

Panel A: Short-term underpricing

\begin{tabular}{|c|c|c|c|c|c|c|c|c|}
\hline \multicolumn{9}{|l|}{ Low returns } \\
\hline IDX & -25.5 & -34.9 & 54 & 0.0101 & 0.0167 & 0.0083 & & \\
\hline Cap_BM_EqW & -63.9 & -63.2 & 30 & 0.0046 & 0.0020 & 0.0113 & & \\
\hline nSEO_VW & -270.7 & -172.7 & 53 & 0.0000 & 0.0000 & 0.0000 & & \\
\hline \multicolumn{9}{|l|}{ High returns } \\
\hline IDX & -40.8 & -43.8 & 55 & 0.0000 & 0.0000 & 0.0000 & 0.2698 & \\
\hline Cap_BM_EqW & -61.8 & -50.0 & 32 & \begin{tabular}{|l|}
0.0004 \\
\end{tabular} & 0.0000 & 0.0007 & 0.8779 & \\
\hline nSEO_VW & -454.8 & -445.9 & 54 & 0.0000 & 0.0000 & 0.0000 & 0.0001 & $* * *$ \\
\hline \multicolumn{9}{|c|}{ Panel B: Company size } \\
\hline \multicolumn{9}{|l|}{ Small companies } \\
\hline IDX & 1.2 & -22.9 & 59 & 0.9397 & 0.9059 & 0.2985 & & \\
\hline Cap BM EqW & -420.0 & -122.8 & 28 & 0.0220 & 0.0011 & 0.0023 & & \\
\hline nSEO VW & -217.6 & -151.9 & 58 & 0.0000 & 0.0000 & 0.0000 & & \\
\hline \multicolumn{9}{|l|}{ Big companies } \\
\hline IDX & -34.5 & -42.7 & 96 & 0.0000 & 0.0000 & 0.0000 & 0.1072 & \\
\hline Cap BM EqW & -43.5 & -47.3 & 67 & 0.0001 & 0.0000 & 0.0002 & 0.0099 & $* * *$ \\
\hline nSEO_VW & -341.8 & -363.7 & 95 & 0.0000 & 0.0000 & 0.0000 & 0.0031 & $* * *$ \\
\hline \multicolumn{9}{|c|}{ Panel C: Issue size } \\
\hline \multicolumn{9}{|l|}{ Small issues } \\
\hline IDX & -25.9 & -41.2 & 82 & \begin{tabular}{|l|}
0.0019 \\
\end{tabular} & 0.0041 & 0.0023 & & \\
\hline Cap_BM_EqW & -267.1 & -97.6 & 27 & 0.0111 & 0.0006 & 0.0023 & & \\
\hline $\mathrm{nSEO} \mathrm{VW}$ & -232.4 & -151.9 & 82 & 0.0000 & 0.0000 & 0.0000 & & \\
\hline \multicolumn{9}{|l|}{ Big issues } \\
\hline IDX & -32.2 & -35.1 & 91 & 0.0000 & 0.0000 & 0.0000 & 0.8391 & \\
\hline Cap BM EqW & -44.7 & -45.1 & 59 & 0.0002 & 0.0001 & 0.0005 & 0.0544 & $*$ \\
\hline nSEO VW & -402.5 & -413.4 & 90 & 0.0000 & 0.0000 & 0.0000 & 0.0000 & $* * *$ \\
\hline
\end{tabular}




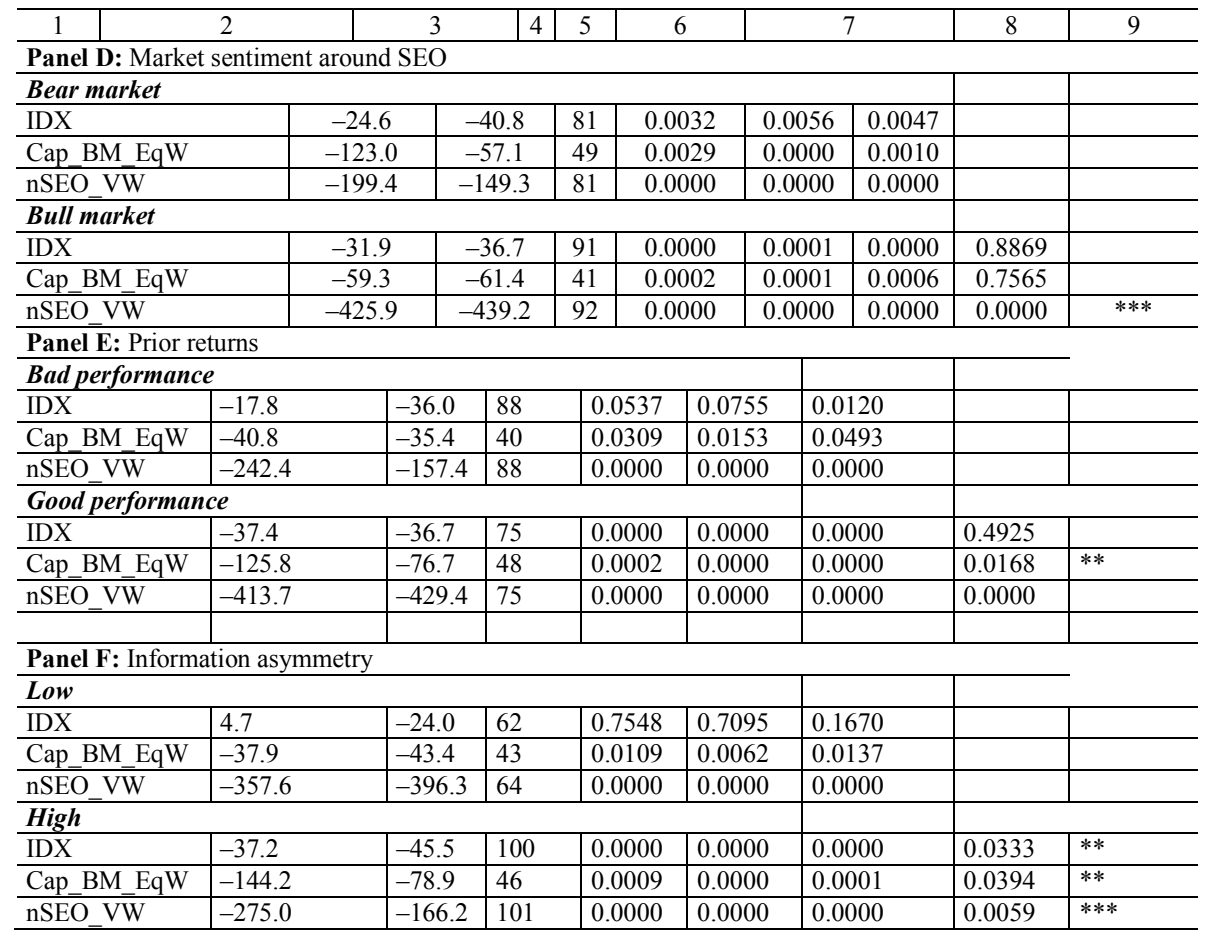

Notes: Statistical significance at the $1 \%(* * *), 5 \%(* *)$ and $10 \%(*)$ confidence levels. The research was based on the following benchmarks: IDX was the BSE 500 Index, nSEO_VW was the value weighted average return on all non-SEO stocks and Cap_BM_EqW was the equally weighted average return on all stocks in the capitalization and book-to-market quartiles.

Source: author's own.

Table 3 shows the performance of SEOs for three-year holding periods (after the first, the second and the third year, 1Y, 2Y, 3Y, respectively) for the selected benchmarks that resulted in the lowest, middle and highest buyand-hold returns (IDX, Cap_BM_EqW, nSEO_VW) and according to six characteristics: the short-term underpricing, the company size, the issue size, the market sentiment around the issue, the prior security returns and information asymmetry around the SEO.

Firms with high short-term returns did not gain in long horizons. Small and big firms did not show a similar pattern according to different benchmarks. This was also observed for small and big issues. Firms that issued during periods of positive investor sentiment (bull market) seemed to underperform more, but the results were significant only for one benchmark. Issuing after a 
period of bad equity performance gave the chance to avoid a relatively big loss during a three-year investment period. However, this anomaly was also revealed for non-issuing companies worldwide as there used to be a positive reversal after a period of lower returns. On the other hand, it could be also explained by the negative market reaction in the period before the flotation, after the announcement of the issue. The information about the future equity issuance could have affected prices to such a huge extent that the market did not incorporate the issue effect afterwards. A significant difference between the groups for all the benchmarks was observed only for information asymmetry. Firms with a lower approximated level of information asymmetry appeared to be, on average, better companies to invest in. However, this relation was quite the reverse for the value-weighted benchmark of non-SEO firms in comparison to two other reference portfolios. The relations appeared to be often mixed according to the reference portfolio used.

\section{CONCLUDING REMARKS}

The academic community has intensely debated the performance of seasoned equity offerings. More specifically, many studies discussed the long-term abnormal returns. The current study contributed to the previous studies in several aspects. First, it provided evidence on the long-term performance of emerging market seasoned equity offerings with the emphasis on the benchmark choice consequences. The results were discussed with many reference portfolios, which is not especially common for non-US studies, especially the emerging markets. Moreover, a possible explanation for SEO underperformance was examined in the context of different reference portfolios. The results support previous studies' conclusions about the long-term underperformance of Indian SEOs drawn upon other adjusting methods (see Deb and Kamisetty 2015 and Deb 2017).

An important conclusion was that the long-term underperformance was very sensitive to the reference portfolio choice and the sample construction. One should be cautious in drawing conclusions about the change in average investor's long-term wealth after seasoned equity offerings. Present patterns might shed light on the empirical implications concerning different benchmarks use in the long-term studies and the importance of reference portfolio choice for the performance observation. A big discrepancy between the levels of underperformance between different benchmarks supports the necessity for further discussion on the design of a better matching method that would control for risk more precisely. 


\section{REFERENCES}

Ahern, K. R., Sample Selection and Event Study Estimation, "Journal of Empirical Finance", vol. 16(3), pp. 466-482, 2009.

Ang, J. S., Zhang, S., Choosing Benchmarks and Test Statistics for Long Horizon Event Study, http://papers.ssrn.com/sol3/papers.cfm?abstract_id=303803\&, January 2002.

Barber, B. M., Lyon, J. D., Detecting Long-run Abnormal Stock Returns: The Empirical Power and Specification of Test Statistics, "Journal of Financial Economics", vol. 43(3), pp. 341-372, 1997.

Bhatia, S., Singh, B., Examining the Performance of IPOs: Evidence from India, "Management and Labour Studies", vol. 37(3), pp. 219-251, 2012.

Deb, S. G., Some Insights into IPO Underpricing in India, "Vilakshan", vol. 6(2), pp. 1-14, 2009.

Deb, S. G, Long-run Performance of Seasoned Equity Offerings. New Evidence from India, "Economic and Political Weekly", vol. 52 (12), pp. 141-148, 2017.

Deb, S. G., Kamisetty, K. C., Long Run Performance of Rights Issues and FPOs: Evidence from India, NSE Working Paper, 2015.

Brav, A., Geczy, C., Gompers, P. A., Is the Abnormal Return Following Equity Issuances Anomalous?, "Journal of Financial Economics", vol. 56(2), pp. 209-249, 2000.

Eberhart, A. C., Siddique, A., The Long-term Performance of Corporate Bonds (and Stocks) Following Seasoned Equity Offerings, "Review of Financial Studies", vol. 15(5), pp. 1385-1406, 2002.

Eckbo, B. E., Masulis, R. W., Norli, Ø., Seasoned Public Offerings: Resolution of the 'New Issues Puzzle', "Journal of Financial Economics”, vol. 56(2), pp. 251-291, 2000.

Fama, E., Market Efficiency, Long-term Returns, and Behavioral Finance, "Journal of Financial Economics", vol. 49/3, pp. 283-306, 1998.

Garg, A., Arora, P., Singla, R, IPO Underpricing in India, "ICFAI Journal of Applied Finance", vol. 47, pp. 33-42, 2008.

Ghosh, S., Underpricing of Initial Public Offerings: The Indian Experience, "Emerging Markets Finance and Trade", vol. 41(6), pp. 45-57, 2005.

Goyal, S., Singh, I., A Study on the Performance of IPOs: An Indian Perspective, "Journal of Management and Technology", vol. 9(1), 2014.

Jegadeesh, N., Long-term Performance of Seasoned Equity Offerings: Benchmark Errors and Biases in Expectations, "Financial Management", vol. 29(3), pp. 5-30, 2000.

Johnson, N., Modified $t$ Tests and Confidence Intervals for Asymmetrical Populations, "Journal of the American Statistical Association", vol. 73(363), pp. 536-544, 1978.

Kothari, S. P., Warner, J. B., Measuring Long-horizon Security Price Performance, "Journal of Financial Economics", vol. 43(3), pp. 301-339, 1997.

Kumar, S. S. S., Short and Long Run Performance of Book-built IPOs in India, 2007, http://dspace.iimk.ac.in/ (8.08.2017).

Li, X., Zhao, X., Propensity Score Matching and Abnormal Performance after Seasoned Equity Offerings, “Journal of Empirical Finance”, vol. 13(3), pp. 351-370, 2006. 
Loughran, T., Ritter, J. R., The New Issue Puzzle, “Journal of Finance”, vol. 50(1), pp. 23-51, 1995.

Loughran, T., Ritter, J. R., Uniformly Least Powerful Tests of Market Efficiency, "Journal of Financial Economics", vol. 55(3), pp. 361-389, 2000.

Lukose, P. J., Rao, S. N., Operating Performance of the Firms Issuing Equity through Rights Offer, "Vikalpa", vol. 28(4), pp. 25-40, 2003.

Lyon, J. D., Barber, B. M., Tsai, C., Improved Methods for Tests of Long-run Abnormal Stock Returns, "Journal of Finance", vol. 54(1), pp. 165-201, 1999.

Madhusoodan, T. P., Thiripalraju, M., Underpricing in Initial Public Offerings: The Indian Experience, "Vikalpa", vol. 22(4), pp. 17-30, 1997.

Marisetty, V. B., Marsden, A., Veeraraghavan, M., Price Reaction to Rights Issues in the Indian Capital Market, "Pacific-Basin Finance Journal", vol. 16(3), pp. 316-340, 2008.

Mayur, M., Kumar, M., An Empirical Investigation of Going-public Decision of Indian Companies, Working Paper Series, 2006-07/06, Lucknow: Indian Institute of Management, pp. 1-45, 2006.

Nandha, M. S., Sawyer, K. R., Ex-ante Uncertainty in Initial Public Offerings: The Indian Market, "Finance India", vol. 16(3), pp. 961-976, 2002.

Pandey, A., Initial Returns, Long Run Performance and Characteristics of Issuers: Differences in Indian IPOs Following Fixed Price and Book Building Processes, Working Paper, Indian Institute of Management, Ahmedabad, 2004.

Sehgal, S., Singh, B., Initial and After-market Performance of Indian IPOs, "ICFAI Journal of Applied Finance", vol. 13(11), pp. 16-36, 2007.

Sehgal, S., Singh, B., Determinants of Initial and Long-run Performance of IPOs in the Indian Stock Market, “Asia-Pacific Business Review, vol. IV(4), pp. 24-37, 2008.

Singh, B., Mittal, R. K., Underpricing of IPOs: Indian Experience, "ICFAI Journal of Applied Finance", vol. 9(2), pp. 29-42, 2003.

Singh, B., Mittal, R. K., Long-run Performance of IPOs in India, [in:] Singh, B., Singh, J. (eds.), Securities Market: Operations and Reforms, pp. 200-214. Deep and Deep Publications Pvt. Ltd., New Delhi, 2005.

Spiess, D. K., Affleck-Graves, J., Underperformance in Long-run Stock Returns Following Seasoned Equity Offerings, "Journal of Financial Economics", vol. 38(3), pp. 243-267, 1995.

Tuli, A., Shukla, A., An Empirical Study on Seasoned Equity Choice between Qualified Institutional Placements and Rights Issues in India, "Decision", vol. 41(3), pp. 279-297, 2014.

Received: October 2013, revised: December 2017 